\title{
THE FINANCIAL SITUATION OF HOUSEHOLDS HEADED BY INDIVIDUALS AGED 50+
}

\author{
SYTUACJA MATERIALNA GOSPODARSTW DOMOWYCH 50+
}

https://doi.org/10.34739/zn.2020.52.05

\author{
Beata Szczecińska
}

Poland, Szczecin West Pomeranian University of Technology, Faculty of Economics ORCID 0000-0002-7718-777X, beata.szczecinska@zut.edu.pl

JEL C11, E21, H24, H31, J14

\begin{abstract}
The article attempts to evaluate Poland's households headed by an individual aged 50 or more. Four household groups were singled out according to the age of the head of the household. These groups corresponded to the old-age subgroups as defined by the World Health Organization. The research used selected parameters of structure and correlation measures. The results of the study showed that in each of the analyzed groups average monthly disposable income per capita exceeded average total expenditure. Approximately half of the respondents perceived the financial situation of their households as barely sufficient, a situation that had practically not changed over the previous year. The results of the research should represent a wake-up call for the authorities of both the state and social local governments to consider the problems of seniors. Ensuring a decent life should not depend on gender, beliefs, physical fitness, health, or age. Analyses, such as that presented here, are a valuable contribution to the development of any policy endeavouring to address the needs of the elderly.
\end{abstract}

Keywords: financial situation, households, ageing society

\begin{abstract}
W artykule podjęto próbę oceny sytuacji materialnej gospodarstw domowych w Polsce, w których głowa gospodarstwa miała 50 lat i więcej. Analizie poddano cztery grupy gospodarstw wyodrębnionych w zależności od wieku głowy gospodarstwa. Pokrywały się one z, zdefiniowanymi przez Światową Organizację Zdrowia, podokresami starości. W badaniach wykorzystano wybrane parametry opisu struktury i miary korelacji. Wyniki przeprowadzonych badań wskazały, że w każdej analizowanej grupie wiekowej przeciętne miesięczne dochody rozporządzalne per capita przewyższały przeciętne wydatki ogółem. Około połowa respondentów oceniła sytuację materialną swojego gospodarstwa domowego jako ledwo wystarczającą, która praktycznie nie zmieniła się na przestrzeni ostatniego roku. Wyniki badań powinny stać się impulsem do pochylenia się nad problemami seniorów przez władze zarówno państwa, jak i samorządów społecznych. Zapewnienie godnego życia nie powinno być uzależnione od płci, przekonań, sprawności fizycznej, zdrowia, a także wieku. Tego rodzaju analizy mają duże znaczenie dla opracowania polityki zaspokajania potrzeb osób starszych.
\end{abstract}

Keywords: sytuacja materialna, gospodarstwa domowe, starzenie się społeczeństwa

\section{Introduction}

Global demographic changes relating to dropping fertility rates and increasing ratios of the elderly in the population are posing new challenges to the governments, manufacturers and economies of regions and countries. This worldwide process is multifaceted, exerting diverse effects on many domains of life. According to Eurostat forecasts (2019), by 2100 the percentage of people aged 80 and more will have grown twice to account for $14.6 \%$ of the overall population. This means that societies will have seen a systematically falling share of the young and an increased share of the elderly requiring assistance and care. These changes call for appropriate preparation to be ensured in advance, as the consequences of demographic ageing are going to be diverse and affect different social processes, such as transformations pertaining to how government expenditure (pension systems) is financed, transformations of consumption and investment patterns, productivity at work, innovation, political preferences, workforce shortages, changes within the science and education domain (Baranowska, 2017, p. 59). The demand structure of the market is going to change, being determined by the financial situation of the elderly on the one hand, and their consumer preferences on the other. 
The aim of this article is to evaluate the financial situation of households in 2018 headed by individuals aged 50 or more. The results of the research will help to supplement the information on the financial situation of elderly people in various age groups, including their place of residence. This information may be helpful when it comes to developing a senior policy in the face of changes in the demographic structure of the population that have been taking place over an extended period of time.

The analyzed data were made available by Główny Urząd Statystyczny (Statistics Poland, or GUS for short) against a fee. They constituted an integrated set of non-identifiable data for 20,879 households. Characterization of the studied population by means of selected parameters of the structure was divided into four age groups of 50-59, $60-74,75-89$ and 90 or more years old. Inclusion of the youngest of the groups in the study may be controversial, but observation of consumer behaviors over time allows for the finding that the perceptive threshold dividing the young and the old has been shifting upwards. The appearance and behavior of a 60 - or 70 -year-old living in the $20^{\text {th }}$ century were different to those of their contemporaries living today. Hence, the current batch of 50-year-olds can be assumed to be the mental and physical idols for the future 60-yearolds. The youngest group was included in the study to show how the financial situation could change after retirement, or following the drawing down of the disability pension by the household head. In addition, the article attempts to investigate the relationship between selected variables characterizing all households headed by individuals aged 50 or more.

\section{Literature review}

The process of consuming goods and services can be looked at as a manner of behavior within a single household or the whole market, or as a manner of behavior affecting the overall structure of the economy. The results of consumption processes analyzed in microeconomic terms should point to the optimal utilization of funds by the consumer or the household (Włodarczyk-Śpiewak, 2011, p. 65). In the age of globalization and continuous competition between enterprises, the knowledge of consumers and their needs, expectations and habits is gaining in significance. Consumer behaviors aim at satisfying specific personal needs, which change with experience, age, family situation, financial standing, etc., with age playing a special role among these variables. With age, consumers' needs change, and so does the manner in which they make their market choices (Malesa and Malesa, 2017, p. 125). The literature on the subject discusses a concept referred to as age complexity (Piotrowska, 2018, p. 470), which applies to a situation where market behaviors or typical products are increasingly more difficult to assign to a particular age group. It should be noted that the older consumer group is not homogeneous, as it includes people in the prime of their life who are still professionally and socially active, elderly persons who are doing well but would embrace some assistive aids tailored to their needs, and physicallyimpaired persons requiring specific products and services.

The concepts of old age and ageing have not yet been defined unequivocally either by the social or biological sciences. The former of the two is treated as a phenomenon or stage in life, while the latter is seen as a process. Old age as a stage or state in human life has a static character, while ageing, perceived as a developmental process, is dynamic in nature. Ageing can be defined as a gradual deterioration of the functional reserve of organs, which reduces the system's capability to maintain balance. This process is continuous and irreversible and resolves in stages. The first to occur is social ageing, construed as the phase in life where the individual retires from work and ceases to play professional roles (Pierzchalska and Klag, 2008, p. 438).

Establishing the threshold behind which one can be regarded as an old-aged person is not easy, as this aspect can be looked at from several different perspectives. The scientists speak of calendar, biological, mental, social, legal, economic, and social age (Szarota, 2010, p. 24-44). Each of these has its own characteristics based on which the given society finds the given person as old or very old. It has been assumed that the most appropriate measure of where old age begins is 60 or 65 years of age. Due to the length of this stage in life, it has become necessary to introduce internal division into the so-called "young old" (60-69 years old), middle old (70-79 years old), "old old" (80-89 years old) and, upon turning 90, very old people (cf. StuartHamilton, 2006, p. 20).

According to the World Health Organization (WHO), the following subgroups of old age are singled out (Klimczuk, 2012, p. 17-18):

- pre-old age, middle (mature) age, middle adulthood, immobile age, non-mobility age, older working age (the 45-59 age range) these are the middle-aged persons,

- ageing, old age, early old age, "third age” (the 60-74 age range) - these are the "young-old" persons,

- senior age, late old age, proper old age, „fourth age" (the 75-89 age range) - these are the "old-old" persons, 
- longevity, long life (aged 90 or more) these are the „oldest old" persons.

Population ageing will lead to the flowering of business ideas and an innovative approach to supplying goods and services. There are many reports noting the so-called silver economy, a phenomenon that has already become an important market trend. This term describes all business activity addressing the needs of the population aged 50 or more (cf. Szukalski, 2012; The Silver Economy, 2015). Such activity is directed at utilizing the potential of the elderly, offers numerous new opportunities and possibilities for development, and begins where manufacturers start perceiving seniors as their potential customers demanding products from the so-called descending sectors. With time, producers begin to modify unfashionable or technologically obsolete products in order to boost their usability. Finally, they roll out products designed for the elderly that account for their specific needs. Thereby, the senior ceases to be a passive buyer and becomes an active consumer. As a result of this, new industries emerge - silver marketing and gerontechnology (Urbaniak et al., 2015, p. 104-105). A true silver-economy mindset begins the moment one's thinking goes beyond these narrow definitions of the target groups. That is, when potential customers cease to be perceived only as individuals but begin to be seen also as groups and organizations, and when the needs being addressed are no longer perceived as those of seniors themselves but rather as those of institutions dealing with seniors. From this point of view, the focus is not only on the elderly but also the pre-old, and supplying services facilitating the prolongation of activity, e.g. employment among the elderly becomes one of the more essential areas of business (e.g. provision of consultancy to enterprises on organizing the working environment and on management methods so as to help them be better prepared for the ageing of the firm's labor force (Szukalski, 2012, pp. 3-4).

The elderly are a specific consumer category, as they typically have a medium or low income at their disposal, which reduces their purchasing power. Their changed socio-economic status has an adverse effect on their lifestyle. Losing their income status and social recognition may lead to them developing low self-esteem (Lena et al., 2009, p. 134). Their deteriorating health adds to the financial management challenges they face (MacLeod et al., 2017). Satisfying material and immaterial needs influences the feeling of satisfaction with life in old age. That is why research on satisfaction with life in old age, conducted by, inter alia, Timoszyk-Tomczak and Bugajska (2013); Wawrzyniak (2015), is so important. There is an urgent need to pay attention to the consequences of ageing both for the near and more distant future.

The social and living situation of older people is one of the issues that in recent years has become the subject of interest to the international community, state governments and parliaments, research centers and non-governmental organizations (Bąk, 2013). However, there are no detailed analyzes explaining the complexity of consumption behavior of individual types of households, including those of seniors. The main motive for undertaking the research is to fill the cognitive gap related to the lack of comprehensive studies on the financial situation of older people. Therefore, in-depth research indicating a worsening of this situation should contribute to an introduction of specific changes pertaining to legal provisions at the central level, as well as the launching of aid instruments at local levels.

\section{Methodology and theoretical basis}

Households are the main entities in the consumption domain. Any evaluation of the financial situation of households depends on the characteristics of the data set used. In Poland, the major source of such information is the household budget studies carried out annually by Statistics Poland (GUS) (e.g. Budżety gospodarstw..., 2019). These studies explore the volumes of revenue and expenditure (both monetary and non-monetary) of all the members of the given household and analyze the quantitative consumption of selected articles and services. Research into the financial situation of persons aged 50 or more has been carried out by, inter alia, Świecka, 2016; Bąk, 2017; Bąk and Szczecińska, 2017.

The present analysis of the financial situation of households headed by an individual aged 50 or more was performed based on a set of separate non-identifiable data on household budgets made available against a fee by GUS. The study focused on the year 2018, and the integrated data set covered 20,879 households. The research used selected parameters of the structure, by which the characteristics of the examined population were synthetically made. The most frequently used in this type of research measures of central tendency, dispersion and asymmetry measures were calculated. The analyzes were carried out using both: classic measures, which are calculated on the basis of the values of the characteristics adopted by all units of the examined population, as well as location measures, determined on the basis of the value of one or several units occupying a special position in this population. A description and the characteristics of these measures can be found in, 
e.g. Zeliaś, 2001; Sobczyk, 2004; Bąk et al., 2015. On the basis of the collected data, contingency tables, which were used in the calculation of measurements determining the strength of the relationship, were constructed. In the case of qualitative variables, and in particular ordinal scales, the following coefficients are most often used: R Spearman, Tau Kendall and gamma (Stanisz 2006, p. 314). The Spearman's rank correlation coefficient was used in the work according to the formula:

$$
R=1-\frac{6 \sum_{i=1}^{n}\left(r_{1 i}-r_{2 i}\right)^{2}}{n\left(n^{2}-1\right)}
$$

where: $r_{1 i}$ - the rank of the $\mathrm{i}$-th object in the first order; $r_{2 i}$ - the rank of the $\mathrm{i}$-th object in the second ordering; $n$ - number of tested objects.

This coefficient indicates both the strength and the direction of the relationship and it takes values from the range $[-1 ;+1]$. Most often, the strength of the relationship is interpreted according to the following scheme:

below 0.2 - weak correlation (practically no relationship),

0.2-0.4 - low correlation (clear correlation),

0.4-0.6 - moderate correlation (significant correlation),

0.6-0.8 - high correlation (significant correlation),

0.8-0.9 - very high correlation (very high correlation),

0.9-1.0 - this relationship is practically complete.

\section{Results and discussion}

In order to gain funds for consumption, household members sell their services that are treated by enterprises as factors of production (human capital). In return for their services, they receive specific income proportionate to their qualifications and the work provided. They primarily spend that income on consumption and savings. Households deliver the most important factor of production, that is labor, without which no economy would be possible, and verify the goods and services thus produced by purchasing and physically consuming them. To put it in brief, the process of social economy begins and ends in the household (Świetlik 2011, p. 3).

According to most definitions, including that provided by $\mathrm{WHO}$, older people are those over 60 years of age. This analysis is primarily intended to show the financial situation of households at this age. However, for comparison, the study also included households where the head was middle- aged (50-59) to check the financial situation of households before reaching retirement age.

Over half of them were households headed by an individual aged between 60 and 74, that is the so-called "young old". A large group $(30.74 \%)$ was made up by pre-old heads of the household, namely persons aged between 50 and 59. Households headed by an individual aged at least 90 accounted for less than $1 \%$. The household budget study data shows that a vast majority of households aged $50+$ are headed by persons not economically active, of whom almost $64 \%$ are pensioners. The second largest group is that of households where the head of the household is employed $(27 \%)$. Only in the case of $2.4 \%$ of households was the head of the household unemployed (sources of income other than employment).

The financial situation of households is strictly related to the volume of their disposable income. According to GUS $^{1}$, this disposable income is the sum of the current income from individual sources minus personal income tax advances paid by the withholding agent in the name of the taxpayer, taxes on income from property, taxes paid by the selfemployed including members of the liberal professions and operators of individual agricultural farms, and social and health insurance contributions. Disposable income includes monetary and non-monetary income, including natural consumption (consumer goods and services procured from one's own individual farm, or from one's own agricultural or non-agricultural business pursued in a self-employed capacity), and goods and services obtained free-of-charge. Disposable income is spent on expenditure and the building up of savings (cf. Begg, 2014, p. 34).

The level of disposable income and total expenditure per capita in the studied households was affected by the respondents' age. The highest average income was characteristic of the youngest study group (Table 1). It has been found that a large majority of this group are economically active individuals. This group was followed by the oldest people's households, with PLN 1,893 per capita, which was probably a consequence of most of them being single-person households. The lowest income was observed in the households headed by persons aged between 75 and 89 .

Household expenditure reflects the process by which the household members' individual and shared needs are addressed. Budget studies indicate that among the households examined herein, the highest average total expenditure was characteristic of those that were headed by persons aged between 60 and 74 , and between 50 and 59 .

\footnotetext{
${ }^{1}$ Definition from the GUS website: https://stat.gov.pl/metainformacje/slownik-pojec/ pojecia-stosowane-w-statystyce-publicznej/63,pojecie.html (date of access: 14/01/2020).
} 
As Table 1 indicates, the distributions of both disposable income and total expenditure are characterized by significant differences that for each group exceed $40 \%$ for income and $50 \%$ for expenditure. Moreover, these distributions are characterized by a very high right-handed asymmetry, which means that in most households the monthly income and expenditure fall below the mean value. It should be pointed out that the youngest household age group (50-59 years old) is characterized by the highest dispersion and asymmetry. The reason for this is clearly the group's different status in the labor market compared to the other age groups. Persons aged 50-59 still remain in the workforce and therefore their income and expenditure cannot be compared to those of the older households. However, when included in the study, this age group helps to highlight significant differences in the financial situation of the households headed by a retiring person, which is why the group was used in further analysis for comparative purposes.

Due to the high diversity and very strong asymmetry for all analyzed age groups, it was decided to calculate selected measures of location in this regard. It turned out that the analysis of these groups in a narrowed area of variability indicates a slightly different characteristic of the distribution of the studied groups. The youngest age group of households has the highest diversity in the case of income, while the oldest group in the case of expenditure (Table 1). Positional measures of asymmetry for most age groups, except the last one, suggests symmetrical distributions, which is the result of the rejection of outliers. Only in the group of $90+$ can we see moderate right asymmetry, which means that for most households, their expenses are below average.

Table 1. Selected descriptive statistics* for the monthly disposable income per capita (I) and total expenditure per capita $(E)$ in households headed by individuals aged 50 or more by age group in 2018

\begin{tabular}{|c|c|c|c|c|c|c|c|c|}
\hline \multirow{3}{*}{ Parameters } & \multicolumn{8}{|c|}{ Age group } \\
\hline & \multicolumn{2}{|c|}{$50-59$} & \multicolumn{2}{|c|}{$60-74$} & \multicolumn{2}{|c|}{$75-89$} & \multicolumn{2}{|c|}{90 or more } \\
\hline & 1 & $E$ & $\mathrm{I}$ & $E$ & 1 & $E$ & $\mathrm{I}$ & $E$ \\
\hline \multicolumn{9}{|c|}{ Classical parameters } \\
\hline $\bar{x}$ & 1,919 & 1,391 & 1,878 & 1,450 & 1,756 & 1,321 & 1,893 & 1,342 \\
\hline$V_{s}$ & 77.67 & 84.8 & 60.25 & 68.83 & 42.29 & 62.73 & 65.67 & 58.94 \\
\hline As & 6.28 & 8.24 & 7.25 & 5.68 & 2.72 & 6.75 & 6.28 & 1.83 \\
\hline \multicolumn{9}{|c|}{ Positional parameters } \\
\hline$M e$ & 1,700 & 1,150 & 1,695 & 1,241 & 1,636 & 1,162 & 1,737 & 1,143 \\
\hline$V_{Q}$ & 35.94 & 36.79 & 26.86 & 33.43 & 23.79 & 32.31 & 26.48 & 37.41 \\
\hline$A_{Q}$ & 0.106 & 0.157 & 0.108 & 0.166 & 0.110 & 0.144 & 0.007 & 0.298 \\
\hline
\end{tabular}

* $\bar{x}-$ mean (PLN), $M_{e}-$ median (PLN), $V_{S}, V_{Q}-$ coefficient of variation (\%), $A_{S}, A_{Q}-$ skewness

Source: the author's own calculations based on separate non-identifiable data from 2018 made available by Statistics Poland.

Accounting for the class of the locality in which the household is situated, convergence with regard to the size of average income per capita, regardless of the type of parameters of centrality (mean, median), within each of the age groups can be observed: the larger the place they live in the higher their average monthly income. The only deviation from this regularity is with the households headed by persons aged 90 or more. If situated in localities with a population ranging between 20 and 99 thousand, these households had a slightly higher income than if situated in places with a population within the 100199 thousand range. As for the average total expenditure, there were more such deviations, e.g. in the group of households headed by persons aged 60-74, the highest average expenditure per capita was observed for localities with a population between 200 and 499 thousand. When examining the relationship between income per person and place of residence, it should be noted that in cities with 500 thousand inhabitants or more, most households 50+ had an income exceeding PLN 2,000 per person (Table 2). On the other hand, in the countryside there dominated households with per capita income ranging from PLN 1,000 to PLN 1,500. The calculated value of Spearman's rank correlation coefficient, statistically significant at the level of 0.05 , was -0.293 , which proves a low relationship between income per capita and the class of locality. The negative correlation indicates that those households living in large cities will earn higher income. The relationship between the expenditure of the surveyed households per capita and the class of the place of residence is similar (Spearman's R coefficient is 0.242). 
Table 2. Contingency table for variables: income per capita and locality class of households headed by individuals aged 50 or more in 2018

\begin{tabular}{|c|c|c|c|c|c|c|c|}
\hline \multirow{2}{*}{$\begin{array}{l}\text { The monthly } \\
\text { disposable } \\
\text { income per } \\
\text { capita (in PLN) }\end{array}$} & \multicolumn{6}{|c|}{ Locality class } & \multirow[b]{2}{*}{ Total } \\
\hline & $\begin{array}{c}500 \mathrm{k} \\
\text { inhabitants } \\
\text { or more }\end{array}$ & $\begin{array}{c}200-499 \mathrm{k} \\
\text { inhabitants }\end{array}$ & $\begin{array}{c}100-199 \mathrm{k} \\
\text { inhabitants }\end{array}$ & $\begin{array}{c}20-99 \mathrm{k} \\
\text { inhabitants }\end{array}$ & $\begin{array}{l}\text { below } 20 \mathrm{k} \\
\text { inhabitants }\end{array}$ & village & \\
\hline 500 or less & 39 & 25 & 27 & 59 & 37 & 346 & 533 \\
\hline$(500-1000]$ & 70 & 78 & 116 & 260 & 213 & 1526 & 2263 \\
\hline$(1000-1500]$ & 313 & 294 & 332 & 919 & 638 & 2914 & 5410 \\
\hline$(1500-2000]$ & 628 & 535 & 495 & 1222 & 766 & 2135 & 5781 \\
\hline Above 2000 & 1182 & 814 & 761 & 1405 & 753 & 1977 & 6892 \\
\hline Total & 2232 & 1746 & 1731 & 3865 & 2407 & 8898 & 20879 \\
\hline
\end{tabular}

Source: the author's own calculations.

In Poland, most senior household expenditure is on food and housing and utility bills. Another important item on their budget is that of medicines and other health products or services. Due to their limited funds, the elderly rarely use hospitality services or involve themselves in active forms of leisure or tourism. The most frequent reasons for these persons to leave their places of residence are to visit their friends or relatives, have a vacation or pursue religious needs (Pierzchalska and Klag, 2008, p. 447; Bąk, 2013, p. 83-87; Bąk and Szczecińska, 2017, p. 192-193).

Apart from quantitative studies, the evaluation of the financial situation of population members should also include a qualitative assessment. The role of qualitative research in studying social phenomena has been discussed by, inter alia, Hossain (2011); Adamska and Szewczuk-Stępień (2012); Worek (2017); Mohajan (2018). Qualitative research is a form of social activity that stresses the importance of how people interpret and attach meaning to their experiences. They allow the understanding of the social reality within which the individuals function and make use of observations and interpretation of how people perceive the different events taking place around them. Their perception reflects their subjective assessment of the quality of their lives. Respondents benchmark their financial situation against that of other people (Akranavičiūtè and Ruževičiu, 2007; Panek, 2014). Therefore, the analysis included three more elements covered by the household budget study:

1) the respondent's assessment of the overall financial situation of the household,

2) the respondent's opinion on whether the financial situation of their household changed over the last 12 months,

3 ) the respondent's description of how spending is managed in their household.

Table 3 shows subjective assessments of the studied households' financial situation. A small number of households in each age group claimed that their financial situation was at least good. Approximately half of the respondents from each group (from $47.9 \%$ of those aged $50-59$ to $59.96 \%$ of those aged 75-89) stated that the financial situation of their household was barely sufficient. Unfortunately, a significant proportion of the households were those with a perceived insufficient or very poor financial situation, ranging from almost $29 \%$ of those aged $75-89$ to even $41.75 \%$ of the youngest heads of the household.

The vast majority of the respondents found that the financial situation of their household had not changed over the last 12 months. Deterioration of their financial circumstances was declared by approx. one-tenth of the households in each age group. A small percentage (from $0.05 \%$ of those aged $75-89$ to $1.18 \%$ of those aged 90 or more) of the respondents admitted that the situation of their household had improved significantly.

The subjective assessments of how money is managed were also analyzed (Table 4). Approximately half of the households headed by persons aged $50+$ were coping with their daily expenses, although they had to save money for some time before they could make more expensive purchases. Worryingly, a large proportion of the respondents (approx. one-third of the persons in each age group) had to be particularly cautious about their daily expenditure. Unfortunately, there were also households that were unable to address their basic needs (from $1.48 \%$ to $2.49 \%$, depending on the age group).

Table 5 presents the contingency table for the subjective assessment of the financial situation of households $50+$ and the class of locality. As shown in the table, most households in which the head of the household was 50 or more, regardless of the place of residence, described their financial situation as barely sufficient. Spearman's rank 
coefficient for these variables was at the level of 0.078 , which indicates no relationship.

The analysis also included the study of the relationship between other variables. It turned out that the statistically significant relationships concerned (the values of Spearman's rank correlation coefficients are given in brackets):

- the monthly disposable income per capita and subjective assessments of the financial situation $(-0.431)$,
- total expenditure per capita and subjective assessments of the financial situation $(-0.255)$,

- subjective assessments of the financial situation and subjective assessments of scale of change of the financial situation in households headed by persons aged $50+$ over the last 12 months (0.272).

Table 3. Subjective assessments of the financial situation of households headed by persons aged $50+$ by age group (\%) in 2018

\begin{tabular}{lcccc}
\hline \multirow{2}{*}{ Assessment } & \multicolumn{3}{c}{ Age group } \\
& $\mathbf{5 0 - 5 9}$ & $\mathbf{6 0 - 7 4}$ & $\mathbf{7 5 - 8 9}$ & $\mathbf{9 0}$ or more \\
\hline very poor & 19.48 & 15.58 & 11.97 & 11.76 \\
insufficient & 22.27 & 19.62 & 16.90 & 21.76 \\
barely sufficient & 47.90 & 53.37 & 59.96 & 53.53 \\
good & 7.57 & 8.84 & 9.03 & 11.18 \\
very good & 2.79 & 2.59 & 2.13 & 1.76 \\
\hline
\end{tabular}

Source: the author's own calculations.

Table 4. Subjective assessments of how money is managed in households headed by persons aged $50+$ by group age (\%) in 2018

\begin{tabular}{lrrrr}
\hline \multirow{2}{*}{ Assessment } & \multicolumn{5}{c}{ Age group } \\
& $\mathbf{5 0 - 5 9}$ & $\mathbf{6 0 - 7 4}$ & $\mathbf{7 5 - 8 9}$ & $\mathbf{9 0}$ or more \\
\hline We can afford some luxury & 1.93 & 1.57 & 0.81 & 1.76 \\
We can afford a lot without having to save much & 16.06 & 12.39 & 10.03 & 13.53 \\
We can afford to by daily necessities, but must save to make & 52.62 & 51.12 & 49.80 & 47.06 \\
more serious purchases & & & & \\
We are forced to manage our finances very carefully every day & 26.89 & 32.69 & 37.88 & 35.88 \\
We cannot afford to address even our basic needs & 2.49 & 2.23 & 1.48 & 1.76 \\
\hline Source: the author's own calculations. & & & &
\end{tabular}

Table 5. Contingency table for variables: subjective assessment of the financial situation of the households headed by persons aged $50+$ and the locality class in 2018

\begin{tabular}{lccccccc}
\hline $\begin{array}{l}\text { Subjective } \\
\text { assessments of } \\
\text { the financial } \\
\text { situation }\end{array}$ & $\begin{array}{c}500 \mathrm{k} \\
\text { inhabitants } \\
\text { or more }\end{array}$ & $\begin{array}{c}200-499 \mathrm{k} \\
\text { inhabitants }\end{array}$ & $\begin{array}{c}100-199 \mathrm{k} \\
\text { inhabitants }\end{array}$ & $\begin{array}{c}20-99 \mathrm{k} \\
\text { inhabitants }\end{array}$ & $\begin{array}{c}\text { below 20 k } \\
\text { inhabitants }\end{array}$ & village & Total \\
\hline very good & 487 & 328 & 378 & 662 & 342 & 1166 & 3363 \\
good & 423 & 382 & 325 & 772 & 556 & 1711 & 4169 \\
barely sufficient & 1094 & 857 & 856 & 2023 & 1265 & 4942 & 11037 \\
insufficient & 170 & 125 & 121 & 305 & 193 & 861 & 1775 \\
very poor & 58 & 54 & 51 & 103 & 51 & 218 & 535 \\
\hline Total & 2232 & 1746 & 1731 & 3865 & 2407 & 8898 & 20879 \\
\hline Source: the author's own calculations. & & & & & & &
\end{tabular}




\section{Conclusions}

A country's current demographic state is one of the most crucial factors determining its social and economic development. In recent years, much attention has been paid to population ageing, a phenomenon largely contributed to by advances in medicine allowing for early diagnosis and treatment of various diseases. Additionally, the elderly are taking care of their physical and mental fitness to a far larger extent than they did in the past, adopting a balanced diet and active lifestyles, and continuing their education. Today's ongoing demographic changes have already many implications in various spheres of life, affecting dynamics and structure of production and consumption, the structure of budget expenditure, the labor market, the system of social insurance and social benefits, investments, saving, social and family relations and lifestyle. The economic instruments of social policy used so far towards the elderly are still insufficient, as evidenced by the results of this analysis. The growing number of seniors has its correlation in their growing needs; therefore, it is necessary to develop long-term solutions, first - at the central level, and then at the local level.

The analysis of the financial situation of households headed by a person aged $50+$ in Poland in 2018 discussed in this article allows for the following conclusions:

1) the average monthly disposable income per capita exceeds the total expenditure per capita in each of the studied age groups of senior households,

2) the larger the locality in which the household is situated, the higher their average monthly income per capita,

3) senior households are generally not very welloff, as they spend their funds mainly on food and housing and utility bills,

4) most of the studied households are not satisfied with their financial situation, while some of them even admit to living on the poverty line,

5) there are interdependencies between the variables characterizing households headed by persons aged $50+$; the strongest relationship was found between income per capita and subjective assessments of the financial situation.

In a situation of rising unemployment, older people may have trouble finding paid employment. Due to the need to ensure a dignified life, health and care for this sensitive social group, we shall require a growing number of state and local government interventions. Analyses such as the present one represent a valuable contribution to the development of a policy addressing the needs of the elderly.
There is a need for further - especially qualitative studies, in order to obtain a deeper insight into the problems being faced today by the elderly.

\section{References}

Adamczyk, G. (2014). Wybrane aspekty zachowań młodych konsumentów w nowych realiach rynkowych [Selected Aspects of Consumer Behaviours Among Young People in the New Market Realities]. Handel Wewnętrzny, 354, 5-16.

Adamska, M. and Szewczuk-Stępień M. (2012). Badania jakościowe jako narzędzie pozyskiwania, analizy i interpretacji wiedzy eksperckiej - wymiar praktyczny [Quality Assessment as an Instrument for the Acquirement, Analysis and Interpretation of Expert Knowledge]. In: M. Adamska and M. Szewczuk-Stępień (eds.), KNOW HOW - efektywna komunikacja w regionalnym transferze wiedzy. Rozwinięcie i synteza wyników. Opole: Instytut Trwałego Rozwoju, 161-180.

Akranavičiūtė, D. and Ruževičiu, J. (2007). Quality of Life and its Components Measurement. Engineering Economics, (2): 43-48. Retrieved from http://www.kv.ef.vu.lt/wp-content/uploads/ 2010/10/STRAIPSNIS-InzEkon_Gyvenimo Darbe Kokybe_2007_Vol.2.pdf.

Baranowska, A. (2017). Starzenie się społeczeństwa europejskiego jako wyzwanie XXI wieku [The Challenges of an Aging European Population in the 21st Century]. Casus Polski. Opuscula Sociologica, 4(22): 55-66, DOI: 10.18276/os.2017.4-04.

Bąk, I. (2013). Statystyczna analiza aktywności turystycznej seniorów w Polsce [The Statistical Analysis of Tourism Activity Among Seniors in Poland]. Szczecin: Wydawnictwo Uczelniane Zachodniopomorskiego Uniwersytetu Technologicznego w Szczecinie.

Bąk, I. (2017). Wydatki gospodarstw 50+ na zagospodarowanie czasu wolnego - analiza statystyczna. Problemy ekonomii, polityki ekonomicznej i finansów publicznych [Household Expenditure for the 50+ on Leisure Activities statistical analysis. Economy, Economic policy and Public Finance]. Prace Naukowe Uniwersytetu Ekonomicznego we Wrocławiu, (475): 33-44.

Bąk, I., Markowicz, I., Mojsiewicz, M. and Wawrzyniak, K. (2015). Statystyka opisowa. Przykłady i zadania [Descriptive Statistics. Examples and Tasks]. Warszawa: Wydawnictwo CeDeWu.

Bąk, I. and Szczecińska, B. (2017). Wydatki gospodarstw domowych 50+ a aktywność ekonomiczna [Household Spending and Economic Activity Among the 50+]. Metody Ilościowe w Badaniach Ekonomicznych, 18(2): 190-199. 
Begg, D. (2014). Makroekonomia [The MacroEconomy]. Warszawa: Polskie Wydawnictwo Ekonomiczne.

Budżety gospodarstw domowych w 2018 r. [Household Budgets for 2018] (2019). Warszawa: Główny Urząd Statystyczny.

European Commission (2018). The Silver Economy - Final Report. Oxford Economics.

Eurostat (2019). Population structure and ageing. Retrieved from https://ec.europa.eu/eurostat/ statistics-explained/index.php?title=Population structure_and_ageing.

Hossain, D.M. (2011). Qualitative Research Process. Postmodern Openings, 7, September, 143-156. Retrieved from https://www.researchgate.net/publication/267798343_Qualitative_ Research_Process.

Klimczuk A. (2012). Kapitał społeczny ludzi starych na przykładzie mieszkańców miasta Białystok [The Social Capital of Elderly People Based on a Study of the Inhabitants of the City of Białystok]. Lublin: Wydawnictwo Wiedza i Edukacja.

Lena, A., Ashok, K., Padma, M., Kamath, V. and Kamath, A. (2009). Health and Social Problems of the Elderly: A Cross-Sectional Study in Udupi Taluk, Karnataka. Indian Journal of Community Medicine, 34(2): 131-134.

MacLeod, S., Musich, S., Hawkins, K. and Armstrong, D.G. (2017). The growing need for resources to help older adults manage their financial and healthcare choices. BMC Geriatrics, 17(84). Retrieved from https://bmcgeriatr. biomedcentral.com/articles/10.1186/s12877017-0477-5.

Malesa, K. and Malesa, T. (2017). Konsumpcja wśród ludzi młodych w Polsce [Consumption Among Young People in Poland]. Zarządzanie innowacyjne $w$ gospodarce i biznesie, 1(24), Akademia Humanistyczno-Ekonomiczna w Łodzi, 125-138.

Mohajan, H.K. (2018). Qualitative Research Methodology in Social Sciences and Related Subjects. Journal of Economic Development, Environment and People, 7(01): 23-48. Retrieved from https://mpra.ub.uni-muenchen.de/85654/1/ MPRA_paper_85654.pdf.

Panek, T. (2014). Poziom i jakość życia [Level and Quality of Life]. In: T. Panek (Ed.), Statystyka społeczna [Social Statistics]. Warszawa: Polskie Wydawnictwo Ekonomiczne, 124-173.

Pierzchalska, A. and Klag, P. (2008). Społeczne role osób starszych [The Social Role of Elderly People]. In: W. Bokajło and A. Pacześniak (Ed.), Równość w Unii Europejskiej - teoria i praktyka [Equality in the European Union - theory and practice]. Wrocław: Wrocławskie Wydawnictwo Naukowe Atla 2, 437-448.
Piotrowska, A. (2018). Przedsiębiorczość wśród seniorów w świetle założeń koncepcji Silver Economy [Entrepreneurial Activity Among Seniors in the Silver Economy]. Przedsiębiorczość i Zarządzanie, XIX (7)3: 469-481.

Siwak, K. (2019). Sytuacja gospodarstw domowych w 2018 r. w świetle wyników badania budżetów gospodarstw domowych [Research Findings on the Situation of Households in 2018]. Warszawa: GUS. Retrieved from https://stat. gov.pl/download/gfx/portalinformacyjny/pl/defau Itaktualnosci/5486/3/18/1/sytuacja_gospodarst w_domowych_w_2018.pdf.

Sobczyk, M. (2004). Statystyka [Statistics]. Warszawa: Wydawnictwo Naukowe PWN.

Stanisz, A. (2006). Przystępny kurs statystyki z zastosowaniem STATISTICA PL na przykładach z medycyny. Tom1. Statystyki podstawowe. [An Introductory Statistics Course with the use of STATISTICA PL. Based on examples from the field of Medicine. Volume1. Basic Statistics] Kraków: StatSoft Polska Sp. z o.o.

Stuart-Hamilton, I. (2006). Psychologia starzenia się [The Psychology of Ageing]. Poznań: Wydawnictwo Zysk i S-ka.

Szarota, Z. (2010). Starzenie się i starość w wymiarze instytucjonalnego wsparcia [Ageing and Old Age in the Context of Institutional Supports]. Kraków: Wydawnictwo Naukowe Uniwersytetu Pedagogicznego w Krakowie.

Szukalski, P. (2012). Srebrna gospodarka. Demografia i Gerontologia Społeczna [The Silver Economy. Demography and Social Gerontology]. Biuletyn Informacyjny, 7. Retrieved from http://dspace.uni.lodz.pl:8080/xmlui/bitstream/ha ndle/11089/3516/2012-7\%20Srebrna\%20 gospodarka. pdf?sequence=1\&isAllowed=y.

Śleszyńska-Świderska, A. (2017). Zachowania polskich konsumentów w warunkach globalnego kryzysu gospodarczego [The Behaviour of Polish Consumers in a Global Financial Crisis]. Białystok: Uniwersytet w Białymstoku.

Świecka, B. (2016). Ocena sytuacji finansowej osób starszych w Polsce ze szczególnym uwzględnieniem zasobności i zadłużenia [The Financial Situation of Elderly People in Poland in Terms of Personal Wealth and Debt]. Problemy Zarządzania, 14/2(59)(1): 118-134.

Świetlik, K. (2011). Zarządzanie budżetem przez gospodarstwa domowe (aspekty teoretyczne i praktyczne) [Managing a household budget (theoretical and practical aspects)]. Handel wewnętrzny, 5(334): 3-11.

Timoszyk-Tomczak, C. and Bugajska, B. (2013). Satysfakcja z życia a perspektywa przyszłościowa w starości [Old Age and Life Satisfaction and Perspectives on the Future], Opuscula Sociologica, 2(4), 83-95. 
Urbaniak, B., Gładzicka-Janowska, A., Żyra, J., Kaliszczak, L., Piekutowska, A., Rollnik-Sadowska, E., Sobolewska-Poniedziałek, E., Niewia-domska, A. and Gagacka, M. (2015). Socjoeko-nomika starzenia się współczesnych społeczeństw [The Socio-economics of Ageing in Contemporary Societies]. Warszawa: CeDeWu.

Wawrzyniak, J.K. (2015). Jakość życia i satysfakcja życiowa w starości [Quality of Life and Life Satisfaction in Old Age]. In: A. Fabiś., Wawrzyniak J.K., Chabior, A., Ludzka starość wybrane zagadnienia gerontologii społecznej. [Human Old Age - aspects of social gerontology]. Kraków: Oficyna Wydawnicza Impuls, 115-124.
Włodarczyk-Śpiewak, K. (2011). Konsumpcja jako przedmiot badań ekonomicznych. [Consumption as an Economic Subject of Research]. Ruch Prawniczy, Ekonomiczny i Socjologiczny, (3): 63-80.

Worek, B. (2017). Metody jakościowe i ich wykorzystanie w pracy socjalnej [Qualitative Methods and their use in Social Work]. Zeszyty Pracy Socjalnej, 22(2): 93-103.

Zeliaś, A. (2001). Metody statystyczne [Statistical Methods]. Warszawa: PWE. 